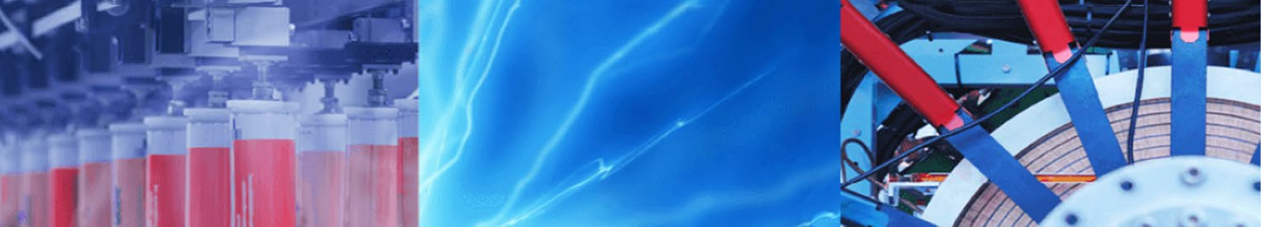

Research Article

\title{
Immobilization of modified zeolite on polyethylene surface: characterization and its application toward phosphate removal and microalgae growth
}

\author{
Zakyeh Akrami $^{1} \cdot$ Susan Norouzi ${ }^{2} \cdot$ Mojtaba Bagherzadeh $^{3}$ (D)
}

C Springer Nature Switzerland AG 2019

\begin{abstract}
Herein, firstly zeolite was modified with $\mathrm{Na}^{+}$and $\mathrm{Fe}^{3+}$ ions and then immobilized on polyethylene surface to construction of modified zeolite coated surface (MZCS). The prepared MZCS was characterized by using XRD, ATR-FTIR, SEM and EDXA techniques and its ability toward phosphate removal was examined and compared with unmodified zeolite coated surface (ZCS). Affecting parameters on phosphate removal were investigated and our results showed the ZCS and MZCS achieved to $32.4 \%$ and $70.6 \%$ phosphate removal ability after $2 \mathrm{~h}$, for $25.0 \mathrm{ppm}$ phosphate at $\mathrm{pH} 7.0$, respectively. The phosphate adsorption results very well fitted in the Langmuir isotherm model for both the ZCS and MZCS. The maximum adsorption capacity as 6.317 and $7.097 \mathrm{mg} / \mathrm{g}$ was observed for the ZCS and MZCS, respectively. Finally, the application of the ZCS and the MZCS for phosphate removal from wastewater and its effect on microalgae growth was tested in two media with three replications. Observed results were presented and discussed here.
\end{abstract}

Keywords Modified surface $\cdot$ Phosphate adsorption - Wastewater $\cdot$ Coated surface

\section{Introduction}

Zeolite, boiling stone [1], is crystalline aluminosilicate with a tetrahedral framework. The structural composition of zeolite results micro-pores and cavities dimensions ranging from 0.3 to $2.0 \mathrm{~nm}[2,3]$. The molecular sieve, resulting from the high void volumes of zeolite, only allows molecules of a certain size (equal to, or less than the pore size) to pass through entry channels, whereas molecules larger than the pore size are excluded [4]. It provides the possibility of using zeolite in collecting and determining different species [5]. Replacing silicons by aluminum in a tectosilicate framework of zeolite, resulting a negative charge in the zeolite framework and consequently lead to bond alkaline or alkaline earth metals to its external surface of zeolite, electrostatically [6-8]. For example, adsorption of cations like $\mathrm{Cu}^{2+}[9], \mathrm{Fe}^{3+}[10], \mathrm{Co}^{2+}[11]$, and $\mathrm{As}^{3+}[12]$, are reported in recent years.

Unlike the adsorption of cations, due to the exciting negative charge on the aluminosilicate framework of zeolite, the efficiency of anions adsorption is low. Therefore, in order to adsorb them, the zeolite surface must be modified by appropriate modifiers. Many investigations have been conducted on improve efficiency of separation and adsorption of anions by using different modifiers. This efforts can be divided to three groups: (1) treatment by acids or bases [13-16], (2) modification by surfactants such as; tetramethylammonium $[17,18]$, cetyltrimethylammonium $[19,20]$, hexadecyltrimethylammonium [21-25], octadecyldimethylbenzyl ammonium [19, 26, 27], n-cetylpyridiminium [28] and polyhexamethylenguanidine [29], and (3) modification by metal ions such as

\footnotetext{
$\triangle$ Zakyeh Akrami, z360_akrami@yahoo.com; $₫$ Mojtaba Bagherzadeh, mjmo123@yahoo.com | 1Department of Chemistry, Farhangian University, Tehran, Islamic Republic of Iran. ${ }^{2}$ Department of Geology, Farhangian University, Tehran, Islamic Republic of Iran. ${ }^{3}$ Reactor and Nuclear Safety School, Nuclear Science and Technology Research Institute, Isfahan, Islamic Republic of Iran.
}

SN Applied Sciences (2019) 1:1183 | https://doi.org/10.1007/s42452-019-1214-9

Received: 12 July 2019 / Accepted: 3 September 2019 / Published online: 9 September 2019 
$\mathrm{Fe}^{3+}$ [30]. For example, Hebuda-Stanic et al. [31] modified zeolite with $\mathrm{Fe}^{3+}$ ions and investigated its ability in arsenic.

However, due to easy modification, ion exchange ability, molecular sieve property, low cost, and high purity of zeolite its applications in catalysis [10], medicinal [32], industrial [33], chemical sensing [9, 34], air separation [35], and removal of heavy metals [36] are more increased. One of the most important applications of zeolites is removal of pollutants from the water and wastewater [37]. The presence of different contaminants such as heavy metal ions [38], organic compounds [39, 40] and inorganic anions [41] in wastewater led to several types of health problems for the aquatic ecosystem. Inorganic anions contain several metalloids [24, 42], metal anions $[43,44]$ and several acid ions such as phosphate $[45,46]$ are present in large volume in the wastewaters.

In this study, the natural zeolite as a low-cost adsorbent was modified and coated to the polyethylene surface. Ability of the modified polyethylene, in phosphate removal from aqueous solution was studied and several techniques are used to trace the events occurred at the surface. The equilibrium studies were carried out and finally applicability of the surface was tested in reducing the algae growth rate in wastewater. Observed results analyzed and discussed here.

\section{Experimental section}

\subsection{Reagents}

Natural Clinoptilolite zeolite was obtained from a mine Semnan Province I.R. Iran. All chemicals were of analytical grade, obtained from Merck company from Germany and used as supplied without further purification. A stock solution of phosphate (100.0 ppm) was made by the dissolution of $0.0358 \mathrm{~g} \mathrm{KH}_{2} \mathrm{PO}_{4}$ in $250 \mathrm{~mL}$ of doubledistilled water. Dilute solutions of phosphate (25.0, 50.0 and $75.0 \mathrm{ppm}$ ) were prepared just before use from a stock solution. All glassware was cleaned with dilute nitric acid $(10 \%)$ and rinsed several times with milli-Q ultrapure water before experiments.

\subsection{Apparatus}

The concentration of phosphate in the solution was determined spectrophotometrically at $400 \mathrm{~nm}$ by $2550 \mathrm{spec}-$ trophotometer, Shimadzu after an equilibrium time. A PerkinElmer 65 spectrometer was used for attenuated total reflectance Fourier transform infrared (ATR-FTIR) investigations and the spectra were obtained in the wave-number range of $400-4000 \mathrm{~cm}^{-1}$. A Philips pw 1800 instrument was used for X-ray diffraction (XRD) measurements and the spectra were performed at a voltage of $60 \mathrm{kV}$ and a current of $400 \mathrm{~mA}$. Scanning electron microscopy (SEM) images and energy dispersive $X$-ray diffraction (EDX) were taken by XL30 Philips the Netherlands. An inverted microscope (Carl Zeiss Microscopy GmbH, Germany) coupled a digital camera was used to take images of cultured cells and the number of algae in images was counted by Neubauer chamber $\left(0.0025 \mathrm{~mm}^{2}, 0.100 \mathrm{~mm}\right.$ Tiefe depth).

\subsection{Modification of polyethylene surface by zeolites}

Firstly, $1 \mathrm{~g}$ of natural zeolite was lightly ground and washed with deionized water and dried in the oven at $250^{\circ} \mathrm{C}$ for $6 \mathrm{~h}$. To prepare modified zeolite, it was pretreatment with $1.0 \mathrm{M} \mathrm{NaCl}$ to obtain Na-form zeolite for $24 \mathrm{~h}$ at room temperature followed by washing with deionized water until neutral $\mathrm{pH}$ and drying at $200 \pm 2{ }^{\circ} \mathrm{C}$. Na-form zeolite was placed in $100 \mathrm{~mL} 0.01 \mathrm{M} \mathrm{FeCl}_{3}$ solution for 3 days at room temperature. Modified zeolite was separated by filtration, washed with deionized water and dried at room temperature. Then, the modified zeolite was dispersed in $2.5 \mathrm{~mL}$ tetrahydrofuran and $2.5 \mathrm{~mL}$ of styrene and a thin layer of this suspension was coated on polyethylene cube $(1 \times 1 \times 5 \mathrm{~cm})$ surface allowed to dry in the air for about $30 \mathrm{~min}$ to prepare MZCS. In the preparation of the ZCS, zeolite was used instead of modified zeolite. The schematic of the surface is represented in Scheme 1.

\subsection{Phosphate adsorption on the surface}

Accumulation of phosphate was performed by immersion of the MZCS in $50 \mathrm{~mL} 25.0 \mathrm{ppm}$ phosphate solution, $\mathrm{pH} 7.0$ using the bath equilibration technique for $2 \mathrm{~h}$ at $500 \mathrm{rpm}$ and $25 \pm 1{ }^{\circ} \mathrm{C}$. After accumulation, the MZCS was removed, the phosphate concentration in solution was analyzed with the vanadomolybdo phosphoric acid colorimetric method $[47,48]$. For comparison, all experiments were performed by the ZCS. Phosphate adsorption efficiency from solution on the ZCS and the MZCS was calculated according to Eq. 1:

Phosphate adsorption $\%=\left(C_{i}-C_{f}\right) \times 100 / C_{i}$

where $C_{i}$ and $C_{f}$ are the blank and final concentration of phosphate in the solution $(\mathrm{mg} / \mathrm{g})$ after adsorption, respectively.

\subsection{Wastewater algae growth experiments}

The wastewater samples obtained from Isfahan ShahinShahr treatment plant and were selected as a culture medium. Three culture mediums were maintained under the same physiological conditions (temperature: $25 \pm 1{ }^{\circ} \mathrm{C}$, photoperiod: $16: 8$ and lightly intensity: $2500 \mathrm{ft}-\mathrm{c}$ ). After 
Scheme 1 Schematic of the ZMCS and its application in phosphate adsorption

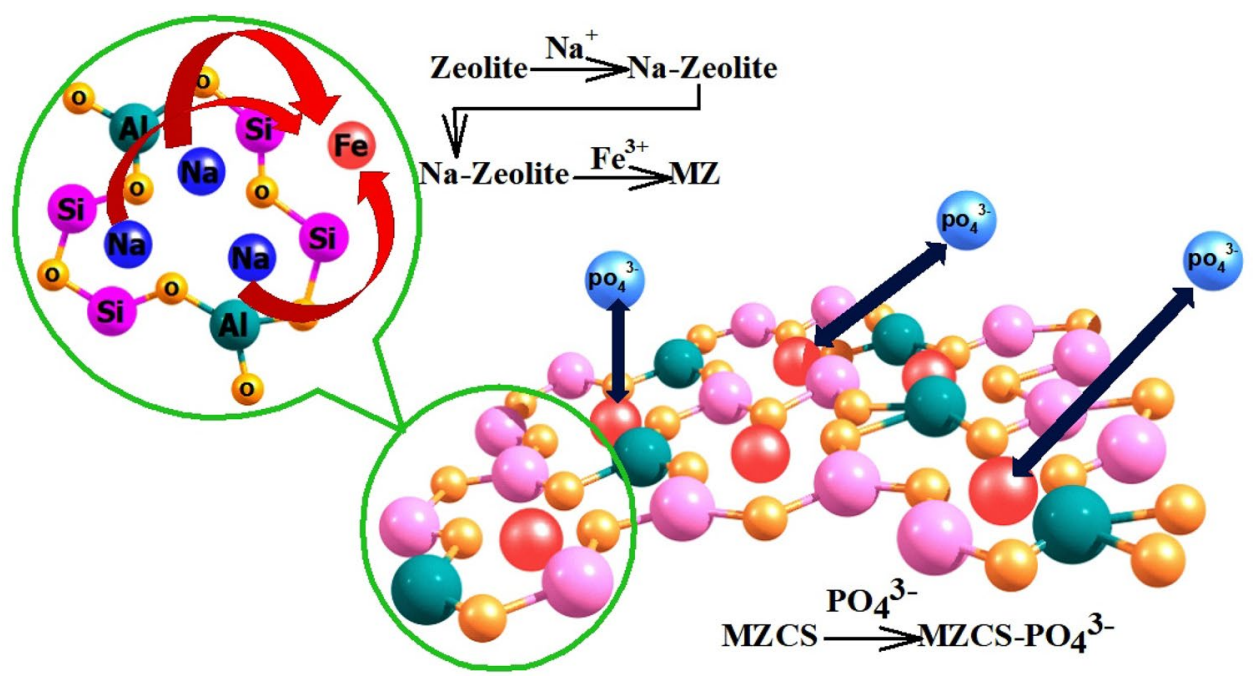

30 days, the number of algae cells per $\mathrm{mL}$ of wastewater was counted using a microscope and Neubauer chamber [49].

\section{Results and discussion}

\subsection{Characterization of modified zeolite by X-ray diffraction analysis}

In order to confirm modification of zeolite, the XRD analysis was taken. According to the XRD pattern (Fig. 1) it can be seen that the used zeolite and modified zeolite in this study were mainly composed of Clinoptilolite, Cristobalite and Gypsum. Calcite, Montmorillonite and Quartz were also found to be low in the zeolite and modified zeolite. As shown in Scheme 1, by modifying the zeolite, $\mathrm{Na}(\mathrm{I})$ ion, cationic radius as 95 pm [50], enters into the zeolite framework. By placing Na-form zeolite in a solution containing $\mathrm{Fe}(\mathrm{III}), \mathrm{Na}$ (I) ions replaced by $\mathrm{Fe}$ (III) ions (cationic radius as $60 \mathrm{pm}$ ) [50] that causes to increasing the cavity size of zeolite [51]. As shown in Fig. 1, the zeolite structure was not changed during the modification and the peak positions for modified zeolite (Fig. 1b) is the same with zeolite (Fig. 1a). Although modification of zeolite by the $\mathrm{Na}(\mathrm{I})$ and the $\mathrm{Fe}(\mathrm{III})$ ions does not affect the overall structure, but
Fig. 1 XRD spectra of the a zeolite and $\mathbf{b}$ modified zeolite

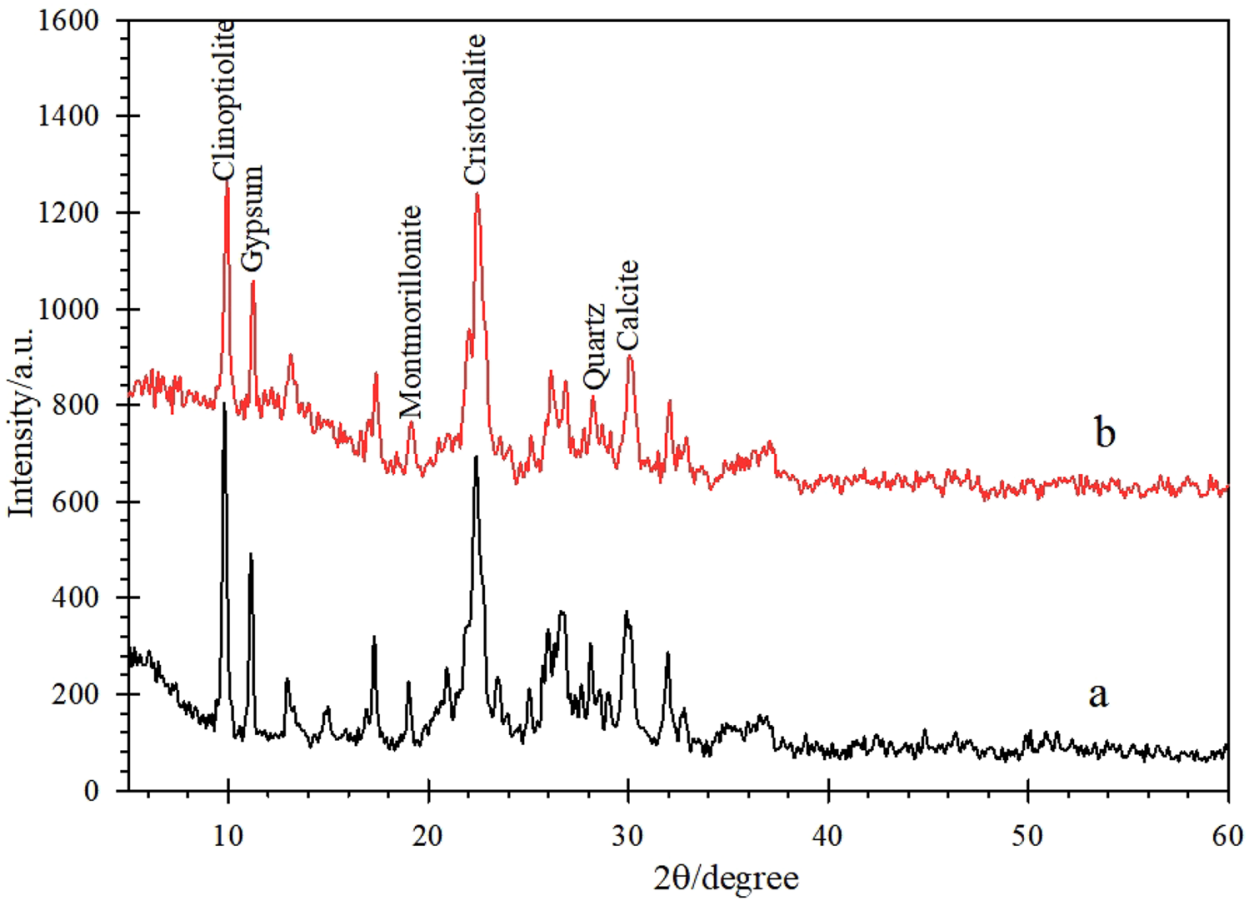

SN Applied Sciences 
changing the channel size of the zeolite affect on its selectivity. The crystalline structure of modified zeolite is less than zeolite that it can be confirmed by fewer peak heights in the modified zeolite XRD spectrum than zeolite (Fig. 1).

\subsection{Effect of parameters on phosphate adsorption on the ZCS and the MZCS}

Effect of contact time on phosphate adsorption at various initial phosphate concentrations $(25.0,50.0,75.0$ and $100.0 \mathrm{ppm}$ ) from solution on the ZCS and the MZCS was investigated (Fig. 2). Results were shown in all phosphate concentrations more than $60 \%$ adsorption was achieved in the initial times for both the ZCS and the MZCS. In the initial time, phosphate can be adsorbed on the inner surfaces of deep pores by diffusion into the sorbent matrix through meso- and micro-pores [52]. Adsorption efficiency was reached a maximum value of $32.4 \%$ after $150 \mathrm{~min}$ for the ZCS and $70.6 \%$ after $120 \mathrm{~min}$ for the MZCS at the same conditions. One of the main reasons for reducing the maximum adsorption time on the MZCS compared with the ZCS can be attributed to the presence of $\mathrm{Na}(\mathrm{I})$ and $\mathrm{Fe}(\mathrm{III})$ ions in modified zeolite at the MZCS. By placing these ions in the zeolite framework, it was created an electrostatic field on the inner surface of the zeolite [51] and was increased adsorption capacity and reduced maximum adsorption time of phosphate ion on the MZCS. According to Fig. 2 adsorption efficiency was reduced with an increase in initial phosphate concentration, therefore $25.0 \mathrm{ppm}$ was chosen for other experiments. Adsorption efficiency of the MZCS decreased by increasing phosphate concentration. This phenomenon may be due to this fact that in low phosphate concentration the adsorbent site on the surface is high and by increasing the phosphate concentration this active cites filled and a repulsive force due to adsorbed phosphate ions expansion on the surface.

The $\mathrm{pH}$ of collecting solution can influence on the surface properties of the adsorbent [53] and therefore strongly affects the mechanism of adsorption on the surface [54]. The point of zero charge $\left(\mathrm{pH}_{\mathrm{PZC}}\right)$ was determined using the $\mathrm{pH}$ drift method and measuring $\mathrm{pH}$ where the zeolite and modified zeolite behave as a neutral species. The $\mathrm{pH}_{\mathrm{PZC}}$ was found to be 7.0 for both zeolite and modified zeolite (Fig. 3, Insets). Adsorption phosphate on the ZCS and MZCS at different $\mathrm{pH}$ were also investigated to determine the optimum $\mathrm{pH}$. For this object, the ZCS and the MZCS were incubated in separate $25.0 \mathrm{ppm}$ phosphate solution at different $\mathrm{pH}$, then each surface was removed after $120 \mathrm{~min}$ and phosphate adsorption of the solution was determined by UV-visible spectrophotometer (Fig. 3). The results were shown that at acidic $\mathrm{pH}$ lower than 4.0, phosphate adsorption was come down due to the dealumination of the zeolite at ZCS and MZCS take place and these were lost crystallinity [55]. When the $\mathrm{pH}$ increased to 4.0-7.0, changes in the crystallinity was not observed and therefore in this range of $\mathrm{pH}$, the percentage of adsorption for both the ZCS and the MZCS was maximal. Similarly, higher adsorption percentage in this region on zeolite was reported by Nemr et al. [56] and Xiong et al. [57]. In pH above than 7.0, there was competition between $\mathrm{OH}^{-}$and phosphate ions in adsorption on the ZCS and the MZCS and according to $\mathrm{pH}_{\mathrm{PZC}}$, repulsion interaction between zeolite and phosphate which led to decrease in phosphate adsorption on both surfaces.
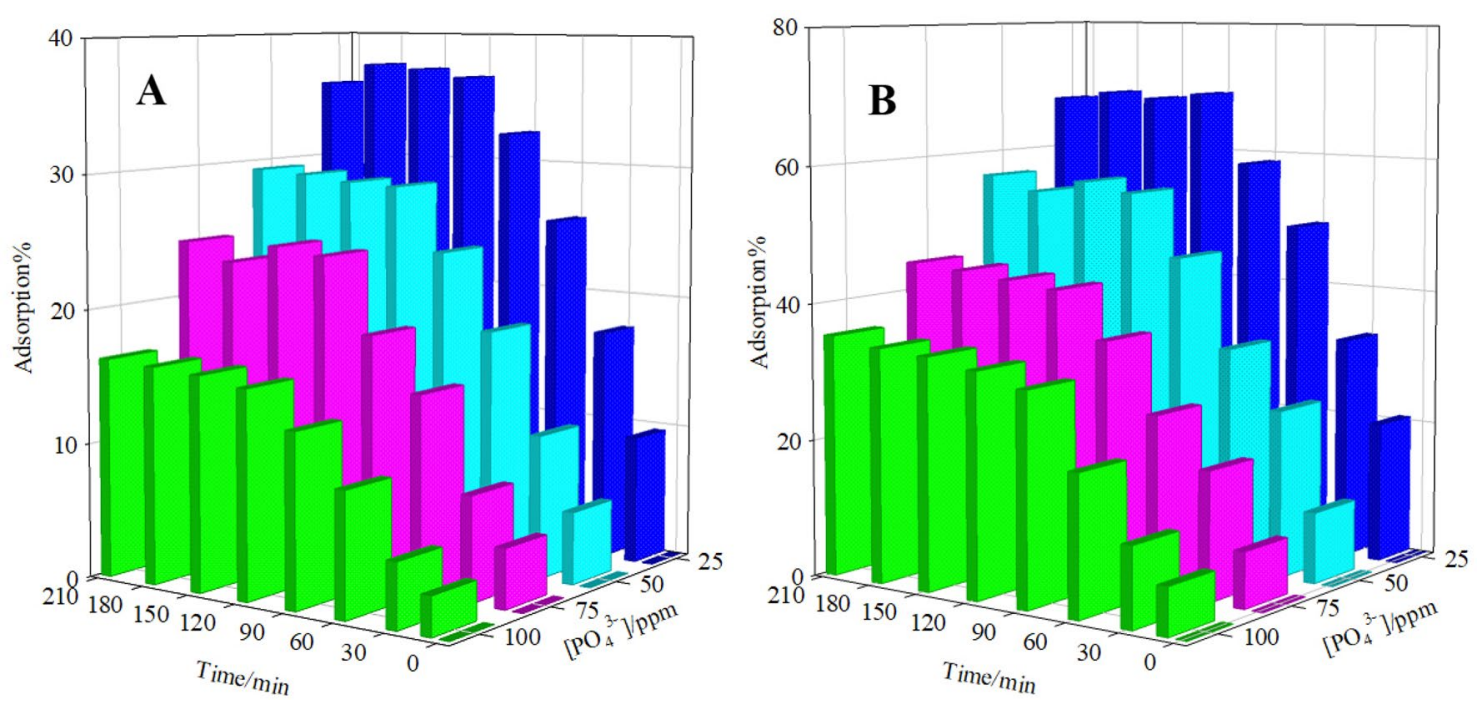

Fig. 2 Effect of phosphate concentration and contact time on phosphate adsorption on the $\mathbf{a}$ ZCS and $\mathbf{b}$ MZCS 
Fig. 3 Effect of collection solution $\mathrm{pH}$ on adsorption of phosphate on the (a) ZCS and (b) MZCS. Insets show the $\mathrm{pH}_{\mathrm{PZC}}$ curves of zeolite and modified zeolite

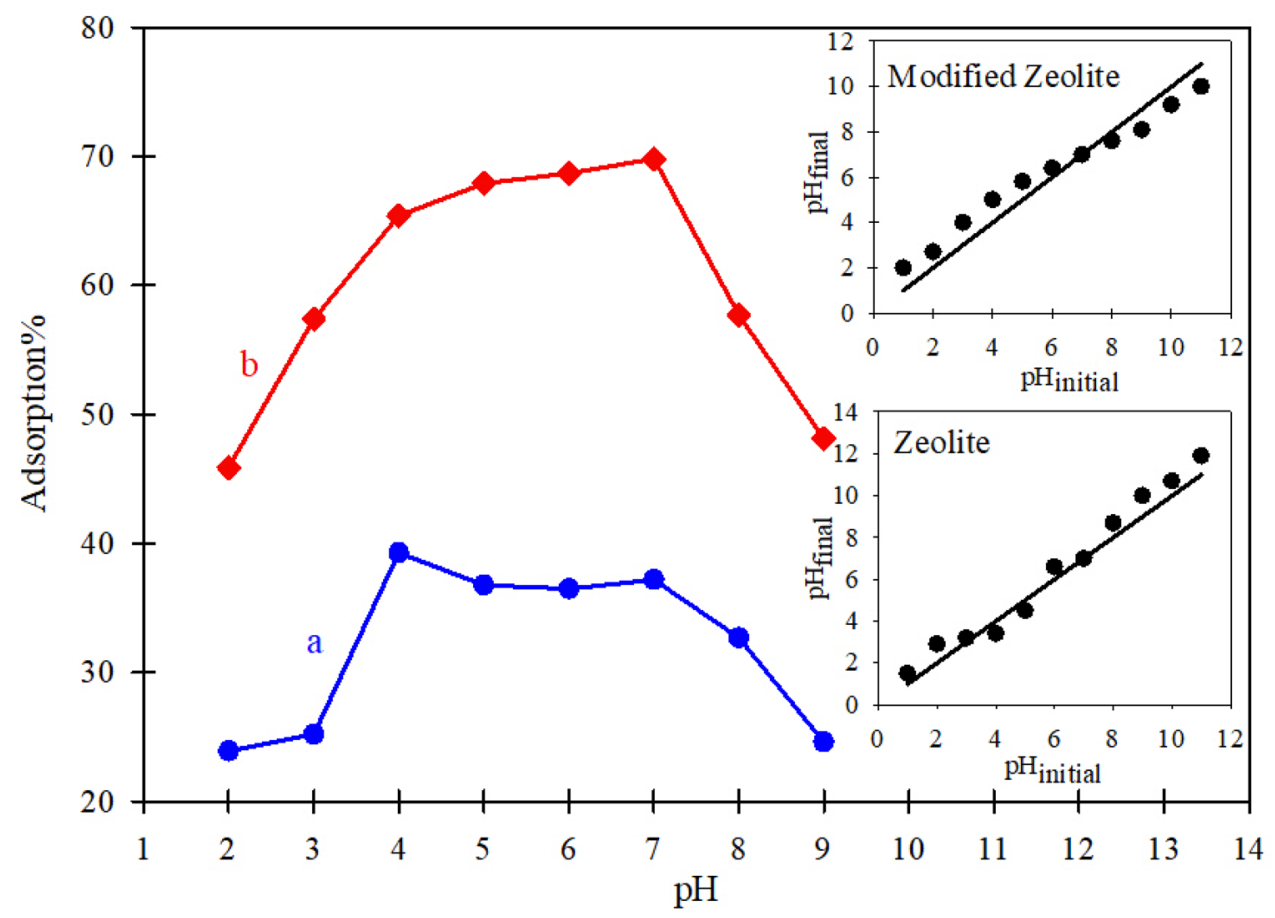

\subsection{ATR-FTIR analysis}

Figure 4 shows the ATR-FTIR spectra for the ZCS and the MZCS. The adsorption band around $1068 \mathrm{~cm}^{-1}$ is attributed to Si-O vibration [58], that the intensity of this band is decreased in the MZCS compared to that in the ZCS. This is due to the introduction of $\mathrm{Fe}(\mathrm{III})$ into the zeolite aluminosilicate framework. The peak at $795 \mathrm{~cm}^{-1}$ corresponds to the stretching vibration of $\mathrm{Al}-\mathrm{O}-\mathrm{Si}$ [59]. A band observed at $469 \mathrm{~cm}^{-1}$ corresponds to Si-O-Si stretching $[58,59]$ and the bands around 3424,2854 and $1637 \mathrm{~cm}^{-1}$ are attributed to $\mathrm{O}-\mathrm{H}$ stretching vibration $[59,60]$. The peaks assigned to
Fig. 4 ATR-FTIR spectra of the (a) ZCS and (b) MZCS

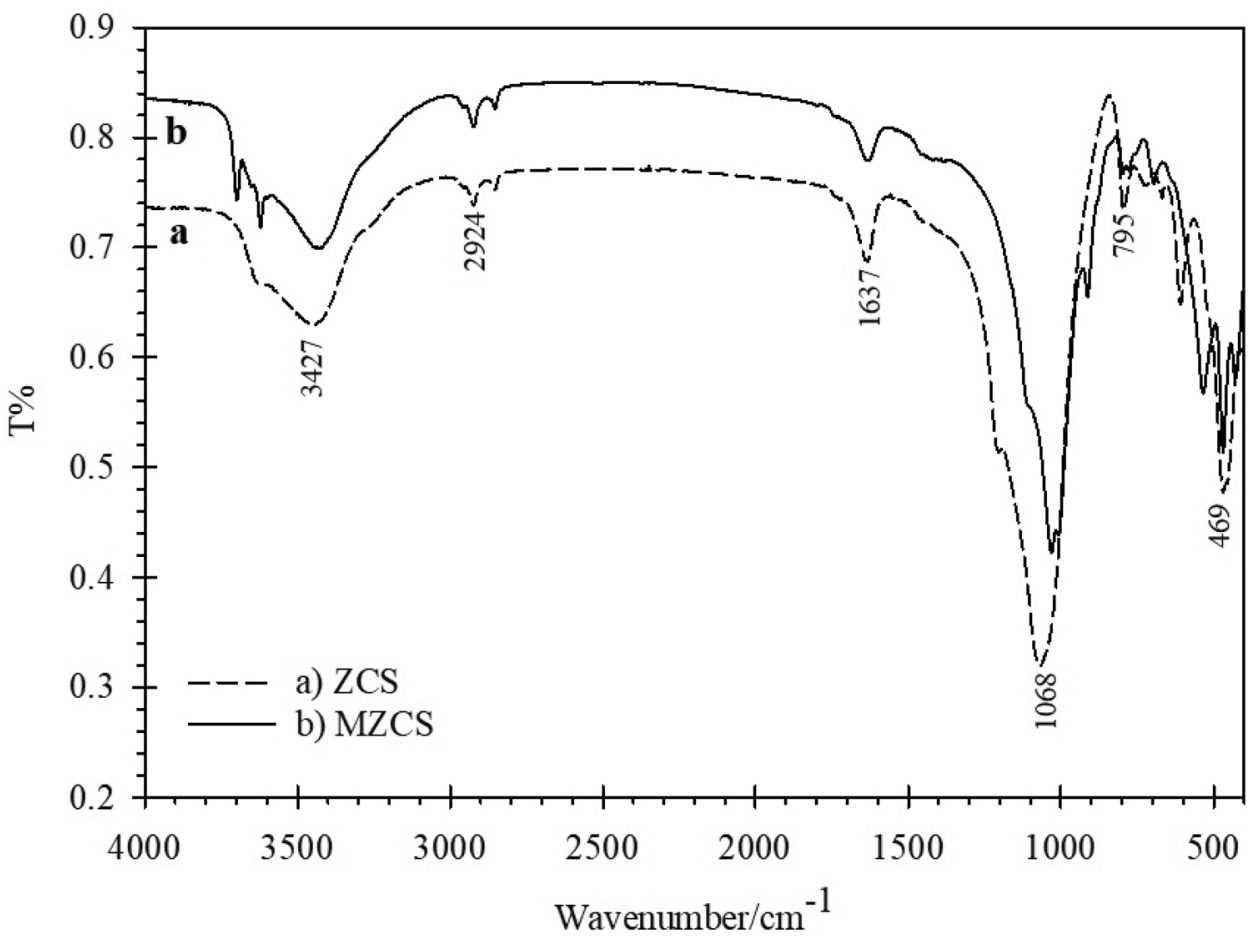

SN Applied Sciences 
$\mathrm{Fe}-\mathrm{O}$ and $\mathrm{Fe}-\mathrm{O}-\mathrm{Fe}$ stretching of Fe-zeolite could not be identified which may be due to the characteristic stretching frequency of silicates [61].

\subsection{SEM and EDX analysis}

To evaluate the possibility and comparison of phosphate adsorption by zeolite and modified zeolite, the morphology of zeolite placed zeolite in $25.0 \mathrm{ppm}$ phosphate solution (zeolite-phosphate) and placed modified zeolite in 25.0 ppm phosphate solution (modified zeolite-phosphate) were examined with SEM and EDX (Fig. 5). The SEM images and EDX spectra were supported that phosphate adsorption on zeolite and especially modified zeolite. The white bulky gatherings and P peak in the SEM images and EDX spectra of zeolite-phosphate and modified zeolitephosphate (Fig. 5B-1, C-1, B-2 and C-2) were demonstrated that phosphate ion was been adsorbed on zeolite and modified zeolite. The higher amount and intensity of that in Fig. 5C-1 and C-2 were confirmed modified zeolite was being successful in adsorbing phosphate ion than zeolite (Fig. 5B-1 and B-2).

\subsection{Adsorption isotherm of phosphate on the ZCS and the MZCS}

To describe the adsorption phosphate isotherm on the ZCS and the MZCS, Langmuir [62-64] and Freundlich [65-67] models were applied and the experimental data were fitted by both models. The values of the correlation coefficient $\left(R^{2}\right)$ of linear plots of both models were considered as an evaluation of the best fit $[68,69]$. Isotherm parameters are reported in Table 1. The values of $R^{2}$ of the Langmuir model were found to be better than that of the Freundlich model for both the ZCS and the MZCS. Table 1 shows the values of $n$ for both the ZCS and the MZCS are longer than 1 that indicates the adsorption of phosphate at both surfaces is favorable $[70,71]$. Compliance experimental data of phosphate adsorption with Langmuir model was suggested that phosphate was adsorbed as a monolayer on both the ZCS and the MZCS [72] and these have equal energy location which each phosphate ion is allocated only to one location, so the distribution of active sites is likely to be adsorbed uniformly and it establishes the strong electrostatic sorbent-adsorbent attraction [73].
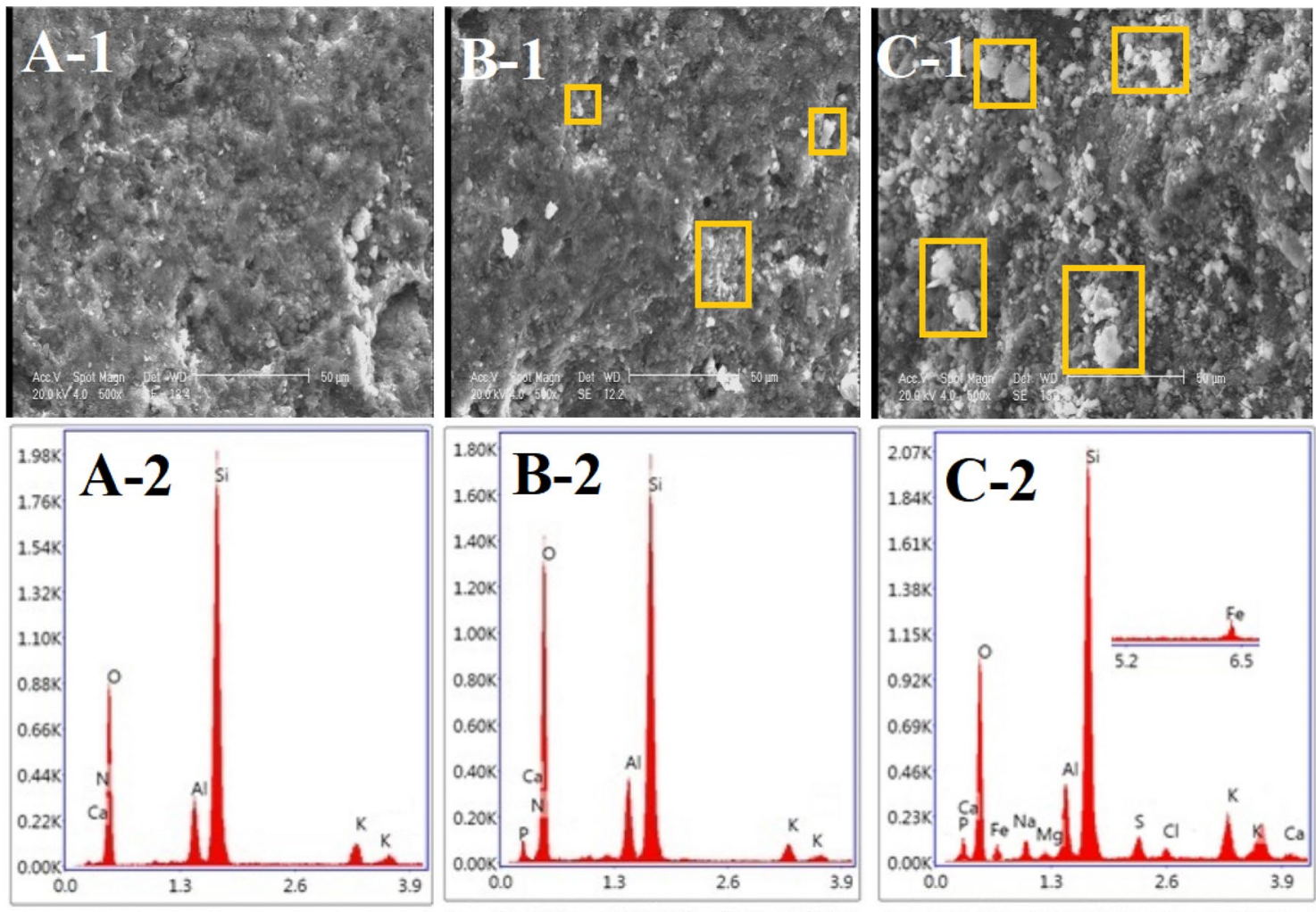

Lec: $13.520 \mathrm{Cnts} 0.260 \mathrm{keV}$ Det Element-C2B Det

Lsec: 10.460 Cnts $0.260 \mathrm{keV}$ Det Element-C2B Det

Lsec: 12.68 Cnts 10.620 keV Det: Element-C2B Det

Fig. 5 SEM image and EDX spectra of the A-1 and A-2 zeolite, B-1 and B-2 zeolite-phosphate, C-1 and C-2 modified zeolite-phosphate. The yellow rectangles show bulky gatherings of phosphate ions 
Table 1 Equilibrium model equations and parameters of the adsorption models fitted to the experimental phosphate adsorption

\begin{tabular}{|c|c|c|c|c|}
\hline Surface & Equation & $\mathrm{R}^{2}$ & $q_{\max }(m g / g)$ & $\mathrm{b}(\mathrm{L} / \mathrm{mg})$ \\
\hline \multicolumn{5}{|c|}{ Langmuir model } \\
\hline ZCS & $\frac{1}{\mathrm{qe}}=0.158+0.723 \frac{1}{\mathrm{Ce}}$ & 0.953 & 6.317 & 0.219 \\
\hline MZCS & $\frac{1}{\mathrm{qe}}=0.141+0.441 \frac{1}{\mathrm{Ce}}$ & 0.9724 & 7.097 & 0.319 \\
\hline Surface & Equation & $\mathrm{R}^{2}$ & $\mathrm{n}$ & $K_{f}(m g / g)$ \\
\hline \multicolumn{5}{|c|}{ Freundlich moldel } \\
\hline ZCS & $\operatorname{lnq} q_{e}=0.379+0.421 \ln C_{e}$ & 0.898 & 2.372 & 1.460 \\
\hline MZCS & $\operatorname{Lnq}_{e}=0.556+0.393 \ln C_{e}$ & 0.877 & 2.546 & 1.743 \\
\hline
\end{tabular}

Langmuir equation: $\frac{\mathrm{Ce}}{\mathrm{qe}}=\frac{\mathrm{Ce}}{\mathrm{qmax}}+\frac{1}{\mathrm{bqmax}}, \mathrm{q}_{\mathrm{e}}=\left(\mathrm{C}_{\mathrm{i}}-\mathrm{C}_{\mathrm{e}}\right) \mathrm{V} / \mathrm{m}, \mathrm{q}_{\mathrm{e}}$ : amount of adsorbed phosphate per unit mass of adsorbent (zeolite or modified zeolite) at equilibrium $(\mathrm{mg} / \mathrm{g}), \mathrm{C}_{\mathrm{i}}$ : initial concentration of phosphate in solution (mg/L), $\mathrm{C}_{\mathrm{e}}$ : phosphate concentration at equilibrium (mg/L), $\mathrm{V}$ : volume of phosphate solution ( $\mathrm{L}$ ) taken, $\mathrm{m}$ : mass of adsorbent used $(\mathrm{g}), \mathrm{q}_{\max }$ : maximum adsorption capacity (mg/g), b: Langmuir adsorption constant (L/mg)

Freundlich equation: $\mathrm{q}_{\mathrm{e}}=\mathrm{K}_{\mathrm{f}} \mathrm{C}_{\mathrm{e}}^{(1 / \mathrm{n})}, \mathrm{K}_{\mathrm{f}}$ : capacity of adsorption (mg/g), $\mathrm{n}$ : intensity of adsorption

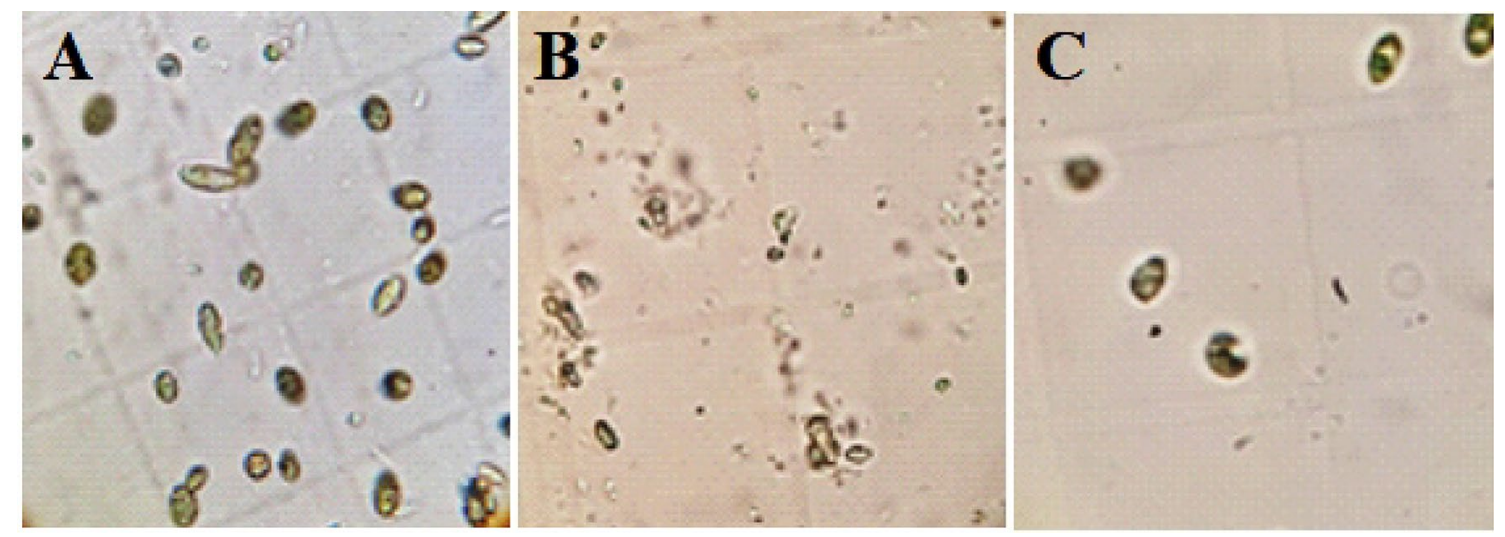

Fig. 6 The Algae growth rate image in a wastewater, $\mathbf{b}$ wastewater containing the ZCS and $\mathbf{c}$ wastewater containing the MZSC

\subsection{Application for wastewater treatment}

The ability of the ZCS and the MZCS for phosphate adsorption and its effect on the growth rate of algae from Isfahan Shahin-Shahr treatment plant wastewater (pH 6.8 and containing 30.0 ppm phosphate) was investigated. The ZCS and MZCS were immersed in $50 \mathrm{~mL}$ of wastewater and maintained under suitable physiological conditions (Sect. 2.5). For comparison, $50 \mathrm{~mL}$ of wastewater was kept under the same physiological condition. After 30 days, the surfaces were removed from solutions, and the growth of algae in wastewater was investigated. Algae were imaged in three culture media: (a) wastewater, (b) wastewater containing the ZCS and (c) wastewater containing the MZCS (Fig. 6). The number of algae cells per $\mathrm{mL}$ of wastewater was counted in each of the three culture media (Table 2). The algae investigating showed that the observed algae were likely to be Chlorella. The results of one-way ANOVA with a 95\%
Table 2 Algae cell number in culture medium (A) wastewater, (B) wastewater containing the ZCS and $(C)$ wastewater containing the MZCS

\begin{tabular}{llll}
\hline Culture medium & A & B & C \\
\hline $\begin{array}{l}\text { Algae cell number } \times 10^{3} \text { (cell/ } \\
\mathrm{mL} \text { ) }\end{array}$ & $3430.7 \pm 10.3$ & $93.4 \pm 5.6$ & $13.2 \pm 1.8$ \\
\hline
\end{tabular}

confidence level showed significant differences between $B$ and $C$ with $A$ culture medium $(P<0.05)$, while there was no significant difference between $B$ with $C$ culture medium $(P>0.05)$. According to Fig. $6 a$ and Table 2 , the wastewater culture medium has the highest algae content due to the nutrient content of phosphate needed for the growth of microorganisms. By placing the ZCS and the MZCS in the wastewater, due to the adsorption of phosphate ions by them, the growth of algae is reduced (Fig. 6 b, c and Table 2). Considering that any micro-algae requires a certain amount of phosphate, 
these results indicate that the ZCS and the MZCS can deliver phosphate in wastewater below the limit for algae growth.

\section{Conclusion}

The selective and suitable surfaces were developed based on zeolite and modified zeolite and examined for adsorption of phosphate in aqueous solution. The capability of the surfaces for adsorption of phosphate was established by XRD, SEM-EDX, ATR-FTIR and UV-visible. The Langmuir isotherm gave the best fit to equilibrium experimental data. The merit of the method of modification includes simple fabrication, low cost, good adsorption efficiency, easy to use, no need for electrical and mechanical power. The validity of the method and applicability of the surface were successfully tested by the removal of phosphate and reducing the algae growth rate in treatment plant wastewater.

Acknowledgements This work is based on a research project in the collection Behin Ab Zendeh Rood knowledge enterprise, Iran's National Elites Foundation and water and Sewage Company of Isfahan. The authors have gratefully acknowledged their contributions.

\section{Compliance with ethical standards}

Conflict of interest The authors declare that they have no conflict of interest.

\section{References}

1. Alberti A, Armbruster T, Artioli G, Colella C, Galli E, Grice JD, Liebau F, Minato H, Nickel EH, Passaglia E (1997) Recommended nomenclature for zeolite minerals: report of the subcommittee on zeolites of the international mineralogical association, commission on new minerals and mineral names. Can Mineral 35:1571-1606

2. Fischer $M(2015)$ Structure and bonding of water molecules in zeolite hosts: benchmarking plane-wave DFT against crystal structure data. Zeitschrift für Kristallographie-Crystalline Materials 230(5):325-336

3. Castaldi P, Santona L, Enzo S, Melis P (2008) Sorption processes and XRD analysis of a natural zeolite exchanged with $\mathrm{Pb} 2+$, $\mathrm{Cd} 2+$ and Zn2 + cations. J Hazard Mater 156(1-3):428-434

4. Byrappa K, Yoshimura M (2001) Hydrothermal synthesis and growth of zeolites in handbook of hydrothermal technology. In: University of Mysore Manasagangotri Mysore, India and Tokyo Institute of Technology

5. Nitzsche R, Groengroeft A, Kraume M (2019) Separation of lignin from beech wood hydrolysate using polymeric resins and zeolites-Determination and application of adsorption isotherms. Sep Purif Technol 209:491-502

6. Armbruster T, Gunter ME (2001) Crystal structures of natural zeolites. Rev Mineral Geochem 45(1):1-67

7. Farkaš A, Rožić M, Barbarić-Mikočević Ž (2005) Ammonium exchange in leakage waters of waste dumps using natural zeolite from the Krapina region, Croatia. J Hazard Mater 117(1):25-33

8. Widiastuti N, Wu H, Ang HM, Zhang D (2011) Removal of ammonium from greywater using natural zeolite. Desalination 277(1-3):15-23

9. Mazloum-Ardakani M, Akrami Z, Kazemian H, Zare HR (2009) Preconcentration and electroanalysis of copper at zeolite modified carbon paste electrode. Int J Electrochem Sci 4(2):308-319

10. Ardakani MM, Akrami Z, Kazemian H, Zare H (2006) Electrocatalytic characteristics of uric acid oxidation at graphite-zeolitemodified electrode doped with iron (III). J Electroanal Chem 586(1):31-38

11. Ardakani MM, Akrami Z, Kazemian H, Zare HR (2008) Accumulation and voltammetric determination of cobalt at zeolite-modified electrodes. J Anal Chem 63(2):184-191

12. Doušová $B$, Grygar T, Martaus A, Fuitová L, Koloušek D, Machovič V (2006) Sorption of AsV on aluminosilicates treated with Fell nanoparticles. J Colloid Interface Sci 302(2):424-431

13. Kurama H, Zimmer A, Reschetilowski W (2002) Chemical modification effect on the sorption capacities of natural clinoptilolite. Chem Eng Technol 25(3):301-305

14. Cakicioglu-Ozkan F, Ulku S (2005) The effect of $\mathrm{HCl}$ treatment on water vapor adsorption characteristics of clinoptilolite rich natural zeolite. Microporous Mesoporous Mater 77(1):47-53

15. Cheng X-W, Zhong Y, Wang J, Guo J, Huang Q, Long Y-C (2005) Studies on modification and structural ultra-stabilization of natural STI zeolite. Microporous Mesoporous Mater 83(1-3):233-243

16. Christidis G, Moraetis D, Keheyan E, Akhalbedashvili L, Kekelidze N, Gevorkyan R, Yeritsyan H, Sargsyan H (2003) Chemical and thermal modification of natural HEU-type zeolitic materials from Armenia, Georgia and Greece. Appl Clay Sci 24(1-2):79-91

17. Bouffard SC, Duff SJ (2000) Uptake of dehydroabietic acid using organically-tailored zeolites. Water Res 34(9):2469-2476

18. Sullivan E, Carey J, Bowman R (1998) Thermodynamics of cationic surfactant sorption onto natural clinoptilolite. J Colloid Interface Sci 206(2):369-380

19. Karadag D, Akgul E, Tok S, Erturk F, Kaya MA, Turan M (2007) Basic and reactive dye removal using natural and modified zeolites. $J$ Chem Eng Data 52(6):2436-2441

20. Karadag D, Turan M, Akgul E, Tok S, Faki A (2007) Adsorption equilibrium and kinetics of reactive black 5 and reactive red 239 in aqueous solution onto surfactant-modified zeolite. J Chem Eng Data 52(5):1615-1620

21. Benkli Y, Can M, Turan M, Celik M (2005) Modification of organozeolite surface for the removal of reactive azo dyes in fixed-bed reactors. Water Res 39(2-3):487-493

22. Bowman RS (2003) Applications of surfactant-modified zeolites to environmental remediation. Microporous Mesoporous Mater 61(1-3):43-56

23. Cortés-Martínez R, Martínez-Miranda V, Solache-Ríos M, GarcíaSosa I (2004) Evaluation of natural and surfactant-modified zeolites in the removal of cadmium from aqueous solutions. Sep Sci Technol 39(11):2711-2730

24. Haggerty GM, Bowman RS (1994) Sorption of chromate and other inorganic anions by organo-zeolite. Environ Sci Technol 28(3):452-458

25. Kuleyin A (2007) Removal of phenol and 4-chlorophenol by surfactant-modified natural zeolite. J Hazard Mater 144(1-2):307-315

26. Daković $A$, Tomašević-Čanović $M$, Rottinghaus $G$, Dondur $V$, Mašić Z (2003) Adsorption of ochratoxin A on octadecyldimethyl benzyl ammonium exchanged-clinoptilolite-heulandite tuff. Colloids Surf B 30(1-2):157-165

27. Daković A, Tomašević-Čanović $M$, Rottinghaus GE, Matijašević S, Sekulić Ž (2007) Fumonisin B1 adsorption 
to octadecyldimethylbenzyl ammonium-modified clinoptilolite-rich zeolitic tuff. Microporous Mesoporous Mater 105(3):285-290

28. Ghiaci M, Abbaspur A, Kia R, Seyedeyn-Azad F (2004) Equilibrium isotherm studies for the sorption of benzene, toluene, and phenol onto organo-zeolites and as-synthesized MCM-41. Sep Purif Technol 40(3):217-229

29. Misaelides P, Zamboulis D, Sarridis P, Warchoł J, Godelitsas A (2008) Chromium (VI) uptake by polyhexamethyleneguanidine-modified natural zeolitic materials. Microporous Mesoporous Mater 108(1-3):162-167

30. Eljamal O, Shubair T, Tahara A, Sugihara Y, Matsunaga N (2019) Iron based nanoparticles-zeolite composites for the removal of cesium from aqueous solutions. J Mol Liq 277:613-623

31. Habuda-Stanić $M$, Kuleš $M$, Kalajdžić $B$, Romić Ž (2007) Quality of groundwater in eastern Croatia. The problem of arsenic pollution. Desalination 210(1-3):157-162

32. Le SD, Nishimura S, Ebitani K (2019) Direct esterification of succinic acid with phenol using zeolite beta catalyst. Catal Commun 122:20-23

33. Hashemi MSH, Eslami F, Karimzadeh R (2019) Organic contaminants removal from industrial wastewater by CTAB treated synthetic zeolite Y. J Environ Manag 233:785-792

34. Ribeiro LEB, de Alcântara GP, Andrade CMG, Fruett F (2015) Analysis of the planar electrode morphology applied to zeolite based chemical sensors. Sens Transducers 193(10):80

35. Kosinov N, Gascon J, Kapteijn F, Hensen EJ (2016) Recent developments in zeolite membranes for gas separation. J Membr Sci 499:65-79

36. Ackley MW, Rege SU, Saxena H (2003) Application of natural zeolites in the purification and separation of gases. Microporous Mesoporous Mater 61(1-3):25-42

37. Gao Q, Xu J, Bu X-H (2018) Recent advances about metalorganic frameworks in the removal of pollutants from wastewater. Coord Chem Rev 378:17-31

38. Huang Y, Zeng X, Guo L, Lan J, Zhang L, Cao D (2018) Heavy metal ion removal of wastewater by zeolite-imidazolate frameworks. Sep Purif Technol 194:462-469

39. Kasperczyk D, Urbaniec K, Barbusinski K, Rene ER, ColmenaresQuintero RF (2019) Application of a compact trickle-bed bioreactor for the removal of odor and volatile organic compounds emitted from a wastewater treatment plant. J Environ Manage 236:413-419

40. Huang Y, Luo M, Xu Z, Zhang D, Li L (2019) Catalytic ozonation of organic contaminants in petrochemical wastewater with ironnickel foam as catalyst. Sep Purif Technol 211:269-278

41. Wang S, Wang J (2018) Radiation-induced degradation of sulfamethoxazole in the presence of various inorganic anions. Chem Eng J 351:688-696

42. Cordoves AP, Valdés MG, Fernández JT, Luis GP, García-Calzón J, García MD (2008) Characterization of the binding site affinity distribution of a surfactant-modified clinoptilolite. Microporous Mesoporous Mater 109(1-3):38-48

43. Samatya S, Yüksel Ü, Yüksel M, Kabay N (2007) Removal of fluoride from water by metal ions $\left(\mathrm{Al}^{3+}, \mathrm{La}^{3+}\right.$ and $\left.\mathrm{ZrO}^{2+}\right)$ loaded natural zeolite. Sep Sci Technol 42(9):2033-2047

44. Faghihian $\mathrm{H}$ (2004) Removal of cyanide from liquid wastes by modified clinoptilolite. Int J Environ Pollut 22(6):732-739

45. Huang H, Zhang P, Yang L, Zhang D, Guo G, Liu J (2017) A pilotscale investigation on the recovery of zinc and phosphate from phosphating wastewater by step precipitation and crystallization. Chem Eng J 317:640-650

46. Jing L, Xuejiang W, Jian W, Yuan L, Siqing X, Jianfu Z (2019) Simultaneous recovery of microalgae, ammonium and phosphate from simulated wastewater by $\mathrm{MgO}$ modified diatomite. Chem Eng J 363:802-811
47. Xi L, Shou D, Wang F (2015) Electrodeposition of monodispersed Cu nanoparticles on poly-p-aminobenzene sulfonic acid functionalized glassy carbon electrode and the electrocatalytic reduction toward $\mathrm{H}_{2} \mathrm{O}_{2}$. J Electroanal Chem 747:83-90

48. Epps $E$ (1950) Photometric determination of available phosphorus pentoxide in fertilizers. Anal Chem 22(8):1062-1063

49. Banerjee S, Hew WE, Khatoon H, Shariff M, Yusoff FM (2011) Growth and proximate composition of tropical marine Chaetoceros calcitrans and Nannochloropsis oculata cultured outdoors and under laboratory conditions. Afr J Biotech 10(8):1375-1383

50. Mortimer C (1983) Chemistry, 6th edn. Wadsworth, Belmont Calif

51. Delkash M, Bakhshayesh BE, Kazemian H (2015) Using zeolitic adsorbents to cleanup special wastewater streams: a review. Microporous Mesoporous Mater 214:224-241

52. Zhu M-X, Ding K-Y, Xu S-H, Jiang X (2009) Adsorption of phosphate on hydroxyaluminum-and hydroxyiron-montmorillonite complexes. J Hazard Mater 165(1-3):645-651

53. Rooyanian S, Bagherzadeh M, Akrami Z, Golikand A (2018) A simple route to surface functionalization of graphene nanosheets by benzoic acid and its application toward $\mathrm{Pb}$ (ii) sensing. New J Chem 42(21):17371-17378

54. Ajouyed O, Hurel C, Ammari M, Allal LB, Marmier N (2010) Sorption of $\mathrm{Cr}(\mathrm{VI})$ onto natural iron and aluminum (oxy) hydroxides: effects of $\mathrm{pH}$, ionic strength and initial concentration. J Hazard Mater 174(1-3):616-622

55. Hernandez-Beltran N, Olguin M, Rosas-Aburto A (2008) Effect of acid phosphate media on the stability of clinoptilolite-rich tuff. J Incl Phenom Macrocycl Chem 61(1-2):93-100

56. El Nemr A, Abdelwahab O, El-Sikaily A, Khaled A (2009) Removal of direct blue-86 from aqueous solution by new activated carbon developed from orange peel. J Hazard Mater 161(1):102-110

57. Xiong X-J, Meng X-J, Zheng T-L (2010) Biosorption of CI Direct Blue 199 from aqueous solution by nonviable Aspergillus niger. J Hazard Mater 175(1-3):241-246

58. Xin X, Si W, Yao Z, Feng R, Du B, Yan L, Wei Q (2011) Adsorption of benzoic acid from aqueous solution by three kinds of modified bentonites. J Colloid Interface Sci 359(2):499-504

59. Ortiz AV (2016) Desenvolvimento de processo de obtenção de nanopartículas de sílica a partir de resíduo de fonte renovável e incorporação em polímero termoplástico para a fabricação de nanocompósito. Universidade de São Paulo

60. Putra EK, Pranowo R, Sunarso J, Indraswati N, Ismadji S (2009) Performance of activated carbon and bentonite for adsorption of amoxicillin from wastewater: mechanisms, isotherms and kinetics. Water Res 43(9):2419-2430

61. Chen J, Zhu L (2009) Comparative study of catalytic activity of different Fe-pillared bentonites in the presence of UV light and $\mathrm{H}_{2} \mathrm{O}_{2}$. Sep Purif Technol 67(3):282-288

62. Chen H, Zhao J (2009) Adsorption study for removal of Congo red anionic dye using organo-attapulgite. Adsorption 15(4):381-389

63. Li L, Liu F, Jing X, Ling P, Li A (2011) Displacement mechanism of binary competitive adsorption for aqueous divalent metal ions onto a novel IDA-chelating resin: isotherm and kinetic modeling. Water Res 45(3):1177-1188

64. Gupta VK, Rastogi A, Nayak A (2010) Adsorption studies on the removal of hexavalent chromium from aqueous solution using a low cost fertilizer industry waste material. J Colloid Interface Sci 342(1):135-141

65. Gupta V, Gupta B, Rastogi A, Agarwal S, Nayak A (2011) A comparative investigation on adsorption performances of mesoporous activated carbon prepared from waste rubber tire and activated carbon for a hazardous azo dye-Acid Blue 113. J Hazard Mater 186(1):891-901 
66. Escudero C, Poch J, Villaescusa I (2013) Modelling of breakthrough curves of single and binary mixtures of Cu (II), Cd (II), $\mathrm{Ni}$ (II) and $\mathrm{Pb}$ (II) sorption onto grape stalks waste. Chem Eng J 217:129-138

67. Triantafyllidis KS, Peleka EN, Komvokis VG, Mavros PP (2010) Iron-modified hydrotalcite-like materials as highly efficient phosphate sorbents. J Colloid Interface Sci 342(2):427-436

68. Bouberka Z, Khenifi A, Sekrane F, Bettahar N, Derriche Z (2008) Removal of 2, 4-DCP from wastewater by CTAB/bentonite using one-step and two-step methods: a comparative study. Chem Eng J 136:295-305

69. Gupta V, Carrott P, Ribeiro Carrott M (2009) Suhas: low-cost adsorbents: growing approach to wastewater treatment-a review. Critical Reviews in Environmental Science and Technology 39(10):783-842
70. Gedik K, Imamoglu I (2008) Removal of cadmium from aqueous solutions using clinoptilolite: influence of pretreatment and regeneration. J Hazard Mater 155(1-2):385-392

71. Ma J, Qi J, Yao C, Cui B, Zhang T, Li D (2012) A novel bentonitebased adsorbent for anionic pollutant removal from water. Chem Eng J 200:97-103

72. Xiong J, Mahmood Q (2010) Adsorptive removal of phosphate from aqueous media by peat. Desalination 259(1-3):59-64

73. Ouadjenia-Marouf F, Marouf R, Schott J, Yahiaoui A (2013) Removal of $\mathrm{Cu}$ (II), $\mathrm{Cd}$ (II) and $\mathrm{Cr}$ (III) ions from aqueous solution by dam silt. Arabian Journal of Chemistry 6(4):401-406

Publisher's Note Springer Nature remains neutral with regard to jurisdictional claims in published maps and institutional affiliations. 